\title{
Technological Capability as a Key Determinant for Foreign Direct Investment: The Case of Indian Sub-Continent
}

\author{
Tahir Iqbal ${ }^{1}$, Abdul Razak Abdul Hadi ${ }^{1} \&$ Sehrish Zafar $^{1}$ \\ ${ }^{1}$ University of Kuala Lumpur Business School, Kuala Lumpur, Malaysia \\ Correspondence: Tahir Iqbal, University of Kuala Lumpur Business School, Kuala Lumpur, Malaysi. E-mail: \\ tahir@unikl.edu.my
}

Received: June 1, 2016

Accepted: July 14, 2016

Online Published: August 10, 2016

doi:10.5539/ijbm.v11n9p154

URL: http://dx.doi.org/10.5539/ijbm.v11n9p154

\begin{abstract}
This paper is pursued with the objective of investigating technological capability as a key determinant for foreign direct investment in Indian sub-continent consisting of India, Pakistan and Bangladesh. The focus of the study is to identify why some countries are attracting more inward FDI than others within the same geographical region as well as to uncover the plausible reason that could lure foreign direct investment (Indian sub-continent caters for one-fifth of the global population). Research methodology uses static panel data models involving fixed and random effects over yearly data from 1994 until 2011. Furthermore, a dynamic panel model via Park method is used on the datasets. The findings which indicate clear implications in those countries with strong domestic technological capabilities seem to have a solid influence in attracting inward FDI. The study also reveals that the relationship between domestic technological development and inward FDI is even stronger than other controlled variables (inflation, lending rates and GDP) in the model.
\end{abstract}

Keywords: foreign direct investment, technological capabilities, panel data, Indian subcontinent

\section{Introduction}

The study focuses on the current ongoing debate about the key determinants of foreign direct investment (FDI) and its effect on economic growth in developing countries, particularly focus on countries in Indian sub-continent: India, Pakistan, and Bangladesh. Within the economies of the Indian sub-continent, there has been growing discussion about how FDI could play a significant role in rejuvenating economic growth. In recent years, new policies from each country show that the region has already recognized that FDI can be a suitable measure to help achieve their economic goals by bringing in foreign currencies, new technology, and employment opportunities. From the global perspective, the trends in foreign direct investment show a $9 \%$ increase in 2013 as much as $\$ 1.45$ trillion. This has been a great improvement since the 2012 global economic slump (UNCTAD, 2014). UNCTAD projects that FDI flows could rise to $\$ 1.6, \$ 1.7$ and $\$ 1.8$ trillion in coming years respectively with significant larger increases are expected in developed countries. Developing Asia remains the leading region with a total of $\$ 426$ billion inflows in 2013 (30\% of the global inflows) (UNCTAD, 2014).

According to the UNCTAD report 2014, the inflows to South Asia rose by $10 \%$ to $\$ 36$ billion in 2013 and become the leading destination for inward FDI in Asia. The largest recipient of FDI in the sub region, India, experienced increases of $17 \%$ (up to $\$ 28$ billion in FDI inflows). Despite the exponential growth in total foreign direct investment (FDI) flows to South Asian countries in the last few decades, the substantial amount of the inflows has directed to limited country. India alone is able to attract $80 \%$ of the regional foreign direct investment (FDI), which is the most effective way to become integrated into the global economy. Pakistan and Bangladesh are still looking for new policies to overcome that problem and identify the key factor, which influences the inward FDI, indicating the urgent need of both economies. This study applies an econometric framework to analyze the countries domestic's technological capabilities (TD) as a key determinant of FDI inflow in Indian sub-continent (India-Pakistan-Bangladesh) in regional level, which has received considerable attention in recent times.

When discussing the country's economic development or inward foreign direct investment, the focus is always on technologies because they play a more central role rather than peripheral. However, there have been a number of studies focusing on FDI, which is the main source to bring new technology to the host countries. This study focuses to analyze the host country technology capabilities as a key determinant of inward FDI. Today 
technologies are considered the main source of knowledge-based production of goods and services by increasing the countries innovative capabilities as well as worker skills, which is the key factor to attract FDI.

Lankes and Venables (1996), Meyer (1998), Cheng and Kwan (2000) Bevan and Estrin (2000) study the reason how Multinationals Enterprises have been attracted by some markets, while the other failed within the same region. These finding suggest that the main reason for attracting the large number of FDI in developing countries is the cheap labor forces and supporting policies toward foreign direct investment (FDI). According to Dutta (2005), the Chinese new economic policy like allowing a fully foreign-owned company and profit repatriation are the main factors that help them attract more foreign direct investment. Today, China is the most attractive FDI destination in the world.

While looking for the overall pattern of Asian FDI, the inflows had also changed several times by moving from key south East Asian countries-Malaysia, Thailand, Philippines to China, Hong Kong and Singapore and at present to India and China. China and India are the leading FDI destinations not only in Asia, but also in the world. It has been argued by many researchers that the reason for this shift is because China and India are able to develop their attractiveness as preferred countries for FDI base on the ability to increase their domestic capabilities such as technology, skillful human resource and develop communications infrastructure (Amitendu Palit, 2007).

The scenario on the pattern of world economies today has also changed dramatically over the past few decades with new virtual markets, liberalization of trade, capital market, with e-trading platforms. There is always a crucial need for developing countries to receive the financial resources, which can be in the form of foreign direct investment or foreign aid (OECD 2010). One of the drawbacks of this is because there is a lack of investment friendly environment which discourages inflow of FDI and these economies mostly depend on foreign aid. This is evident in the case of Pakistan, an economy which is mostly dependent on foreign aid (OECD 2010).

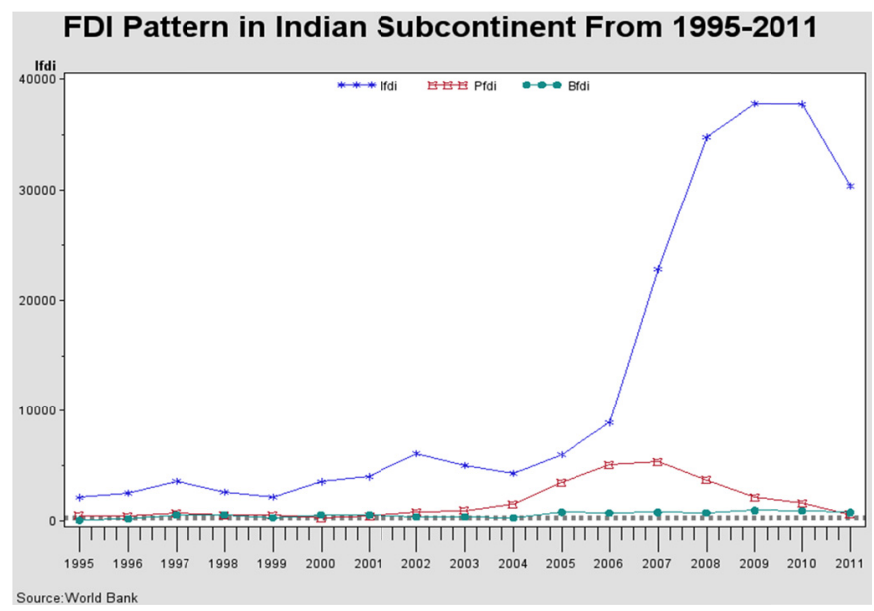

Figure 1. Pattern of FDI inflow in Indian subcontinent

$($ Ifdi= India FDI $)($ Pfdi= Pakistan FDI $)($ Bfdi $=$ Bangladesh FDI $)$

Furthermore currently, the global economy is more capable of changing quickly and dramatically, and having different effects on each country's economy at different times. Therefore, many economic models are incomplete by exploring the complementary conditions to address the particular problems, which cause the countries FDI inflow and economic growth.

The software industry in India produces high quality of product with low price, which attracts foreign companies to start their operations in India. Today India is considered a global home for advanced technological workforce, and supplies skilled computer professional to the world market. The software industry is the primary supporting industry that gives a new shift to Indian economy by providing high rank technologies availability in the domestic market. Nasscom (2014) expects that Indian IT export business will meet the lower end of 11\%-14\% growth in FY15. Besides information technology, India is showing high growth in different technological component, which attracts a number of foreign investors to invest in India. 
A number of research studies developed different models aiming to explain key determinants of FDI, but these variables may have different impact in different countries. Our second aim is to provide and explain the reasons why some countries are attracting more FDI than the other within the same region by analyzing the key role of country domestic technology capabilities. The role of technology capabilities to attract Foreign Direct Investment (FDI) in Indian sub-continent is un-examined. This paper attempts to fill the gap in existing literature by analyzing the domestic technological capabilities as a main determinant of Foreign Direct Investment (FDI) in Indian sub-continent (India-Pakistan-Bangladesh).

\section{Contribution of the Study}

A number of research studies recognized foreign direct investment (FDI) as a channel for new technologies, transformation or technology spillover (Judith D Singer, 1998). Importing advanced technology can enable the domestic producer to produce similar goods at a lower cost at home. However, there have been very limited researches carried out to study the other aspect, which is domestic technological gap between the countries can be a determinant of the level of foreign presence in the country. Therefore, our study aims to contribute to the ongoing debate by exploring the countries domestic's technological capabilities (TC) as a determinant for inward FDI in Indian sub-continents in regional level. Furthermore, a number of study are focused on individual country determent of FDI in India sub-continent, but very limited research studies are focused to identify the key determinants of regional inward FDI in to Indian sub-continent (India, Pakistan, and Bangladesh).

A number of research studies indicate that cheap labors, a large market size, and natural resourcesare the key determinants for attracting Foreign Direct Investment (FDI). While looking into the Asian Development experiencing high labor cost, countries with low population such as Korea, Hong Kong, and Singapore are attracting more foreign direct investment (FDI) compared to countries with high population and low labor cost like Indonesia, Pakistan, Bangladesh, and Thailand. This is because new technological innovations are regularly changing and improving the way we do business and how we approach to develop our business or economic model. Business and production processes that have been unchanged for decades are now re-designed with the aid of technology.

\section{Literature Review}

Ever since Hymen (1960) proposed his idea on foreign direct investment (FDI), there has been ongoing debate about the key factor that attracts FDI and how this could enhance understanding of policy related to FDI in today's global business environment. Hymer (1960) introduces the Ownership Advantage Theory, which considers ownership advantages as a determinant for inward foreign direct investment (FDI), and this is followed with a product life cycle theory by Vernoon, (1966) and OLI Paradigm Theories by Dunning (1980), which aims to identify the key factor that attracts FDI.

However, a number of studies which only focuses on individual country, such as Banga (2003) pointed out that low wages in India is the key factor that attracts more investment in India. Guha, (2004) also comes up with the same finding in his research study, which gains our attention to Pakistan and Bangladesh, whereby wages are much lower than Indian market, but they are still not able to attract more FDI. Pakistan and Bangladesh must gain high Foreign Direct Investment (FDI), considering the fact that low labor cost is a key determinant in Indian sub-continent, which still needs further investigation. This indicates more open sources of comparative advantages that lower labor cost is no more the key determinant to attract foreign direct investment (FDI). This also indicates that globalization leads to some new economic factors, which are directly influencing countries FDI inflow (Smith, 1997; Evangelista, 1999). Below is some of the literature from study focus on determinist of inward FDI.

Summary (1995) stressed in his finding that political instability and uncertainties directly affect the FDI inflow in Pakistan. While Amitendu Pitt (2007) in his research argues that government policy is the leading factor in attracting FDI in Indian sub-continent. A study by Tuan and Ng (2004) indicates that government decision could influence FDI flow by providing stable policies, removing the trade barriers, tax relaxation and foreign exchange rate control, etc. Dunning (1993) and Moosa (2002) study the microeconomics perception and their finding shows that political stability and risk are the key determinant of a particular location, while Nakamura and Oyama (1998) find that exchange rate affects the FDI inflow into the Asian countries. Furthermore, Carr et al. (2001) stress more on knowledge Capital, Technology Transfer, and Desai (2005) focuses on economic growth and provides calculation that economic growth could itself lead to FDI inflows. With high technological growth today, India managed to achieve macroeconomic stability and impressive rates of economic growth. The role of rapid technological development in country's overall productivity gain and production process efficiency is 
self-avoidance (Caves, 1996). Multinational Corporations (MNCs) always seek to exploit the technological capabilities of host countries before they move into the country's market.

Avoidance from Asian market is clear that a country which gains large FDI in recent years has shifted its country comparative advantages of low labor cost to high advance technological capabilities and provides high skills technologies expertise. (Carlos Barros, 2013). While looking into the history of the Indian subcontinent, Pakistan was the leading economy, followed by India and Bangladesh. And today India becomes the leading Foreign Direct Investment (FDI) destination in the world. According to the World Bank report insecure business environment, political instability, high level corruptions is the key negative factor, which affects Foreign Direct Investment (FDI) in Pakistan and Bangladesh (World Bank Report, 2012).

To the best of our knowledge, there is no comprehensive empirical research on the determinants of FDI in Indian sub-continents, but a substantial body of literature exists in respect to other countries. However, we agree that the aim of FDI is to seek, develop and exploit domestic market's resources more efficiently which needs to be analyzed further.

\section{Theoretical Framework}

Several standard Internationalization Theories can be considered in explaining foreign direct Investment (FDI) pattern in Indian sub-continent. Hymer (1960) first introduces an 'Ownerships Advantages Theory' to explain the key determinants and motivation for FDI. Vernoon (1966) introduces the Product Life Cycle, which focuses on different stages of FDI inflow.

Theoretical framework of foreign direct investment (FDI) can be divided into two categories: macro level and micro level. At macro-level, we have a Capital Market Theory focusing on interest rates which is the key determinate of FDI inflow. On the other hand, the Dynamic Macroeconomic Theory is more focused on timing of the investment depends upon the changes in the macroeconomic environment. Furthermore, FDI Theories are based on exchange rates focus on the relationship of FDI flows and exchange rate, and suggest that FDI can reduce the exchange rate risk. At the micro-level, we have the Hymen Theory based on the existence of firm specific advantages to reduce transaction costs by integrating together according to the country specific advantages. Furthermore, Oligopolistic Market FDI Theories focus on oligopolistic markets whereby the companies follow the actions of the market leader.

Internalization theory tries to explain the growth of transnational companies and their motivations to invest outside the country and a company entry to the foreign market. However, in this research, we are adopting Eclectic Paradigm Theory by Dunning (1980), which is also known as OLI Theory. This theory was published by John H. Dunning in 1980 and is considered one of the core theories of FDI in recent time.

The Eclectic Paradigm Theory is based on three main factors: Ownership (O) advantages, location (L) advantages, and Internalization (I) advantages. These three factors help determine which countries are more suitable for foreign production and give measurement parameter for corporation while they are investing abroad. This study focuses on identifying the location advantages only as a key determent of FDI by analyzing the domestic technology capabilities as a key determent of Foreign Direct Investment (FDI) inflow in Indian sub-continent.

\subsection{Data \& Variables}

\begin{tabular}{ll}
\hline Variables & Explanation \& Data source \\
\hline Technology development & Weighted average of three parameters. \\
$1 . \quad$ Manpower engaged in R\&D \\
$2 . \quad$ Patents taken out \\
3. Scientific Articles published \\
( Each equal weight) \\
Data Source: IMF, World Bank. \\
Inflation is measured by the consumer price index which reflects the annual percentage change \\
in the cost to the average consumer of acquiring a basket of goods and services that may be \\
fixed or changed at specified intervals, such as yearly. The Laspeyres formula is generally used. \\
Data Source: IMF, World Bank. \\
Lending rate is the bank rate that usually meets the short- and medium-term financing needs of \\
the private sector. This rate is normally differentiated according to credit worthiness of \\
borrowers and objectives of financing. The terms and conditions attached to these rates differ by
\end{tabular}


country, however, limiting their comparability.

GDP growth Rate \% Data Source: IMF, World Bank.

The annual percentage growth rate of GDP at market prices based on constant local currency. Aggregates are based on constant 2005 U.S. dollars. GDP is the sum of gross value added by all resident producers in the economy plus any product taxes and minus any subsidies not included in the value of the products. It is calculated without making deductions for depreciation of fabricated assets or for depletion and degradation of natural resources.

Data Source: IMF ,World Bank.

\section{Methodology}

Recently, several studies have adopted different statistical approaches to analyze inward FDI that can be a time series model, cross section model or combination of both (panel data model). In this study, we will analyze the sample data using three different methods within a panel data setup, namely, Pooled (OLS), Fixed Effect Model, Random Effect Model. Panel data model covers both time series data and cross-section data. Several studies argue that (Attaullah, 2006) the cross section method alone can lead to biased results due to not account for heterogeneity (diversity). Furthermore, panel data increases the sample size, and leads to more accurate result as compared to time series or cross section alone. Panel data model (PDM) can be expressed as follows:

$$
P D M=Y_{i t}=\alpha_{i}+\gamma_{t}+\beta X_{i t}+U_{i t}
$$

Where $\mathrm{i}=1,2,3, \mathrm{~N}$ : and $\mathrm{t}=1,2,3, \mathrm{~T}$

Where:

$\mathrm{u}_{\mathrm{it}}=$ Error term effect;

$\alpha_{\mathrm{i}}=$ individual effects (Cross Sectional);

$\Upsilon_{t}=$ Time series effect;

Total sample size $=\mathrm{N} \times \mathrm{T}$.

Furthermore, panel data approach is preferred in studying the dynamics of changes. Park (2005) argues that panel data model is good as it will observe the variable with respect to its cross sectional dimension and time series dimension (within the effect and between effects). Within panel data setup (with respect to fixed effect model), the intercepts vary across time and groups. In the case of random effect model, however, the error variances vary across groups and time. A slope is constant in both fixed and random effect models and our key focus will be only on the intercepts and error variances. In addition, the main reason to adopt the panel data setup is the fact that many researchers agree on panel data model that has the capacity to handle more complicated behavioral models like culture issue, technological changes, etc. (Greene, 2003; Hausman, 1978). Panel data may have group effect or time effects and could be both. As such, the data sample will be analyzed using fixed effect and random effect models (Breusch, 1980).

In a fixed effect models, the individual variation and time series variation will go to intercept. Once we target the intercept, some kinds of impact will go to the error term. The moment it will go to error component, we will study the error observation. For error, observation, the standard assumption will be that the intercept will remain constant.

In Fixed Effect models: $Y_{i t}=\alpha+\mu_{i}+\beta X_{i t}+u_{i t}$ (In case of variation on ' $i$ ' and ' $t$ ' the effect will go to intercept).

In Random Effect Models: $\mathrm{Y}_{\mathrm{it}}=\alpha+\beta \mathrm{X}_{\mathrm{it}}+\left(\mathrm{U}_{\mathrm{it}}+\mathrm{V}_{\mathrm{it}}\right)$ In case of variation on 'i' and ' $\mathrm{t}$ ' the effect will go to Error Term.

To discuss further, the study will analyze the data using pooled data model as per mention below. In case of Pooled data model the usual structure is

$$
Y_{i t}=\alpha+\beta X_{i t}+U_{i t}
$$

Once OLS techniques are adopted, we will have some fundamental assumptions that need to be fulfilled before we can proceed further.

Assumption 1: $\operatorname{Cov}\left(\mathrm{U}_{\mathrm{it}}, \mathrm{U}_{\mathrm{j} t}\right)=0$ (Presence of homoscedasticiy) Cov $=$ Covariance of $\mathrm{U}_{\mathrm{it}}$

Assumption 2: $\operatorname{Cov}\left(\mathrm{U}_{\mathrm{it}}, \mathrm{U}_{\mathrm{it}-1}\right)=0$ (Absence of autocorrelation)

Assumption 3: $\mathrm{E}\left(\mathrm{U}_{\mathrm{it}}\right)=0$ (Presence of Normality) 


\section{Assumption 4: Variance $\left(\mathrm{U}_{\mathrm{it}}\right)=\sigma^{2} \mathrm{U}$ (Presence of homoscedasticity)}

Once all the four conditions are satisfied, we can proceed with estimation process using two different methods. First, having "i" (cross section) constant with variation in " $\mathrm{t}$ " (time series). Next, having "t" (time series) constant while "i" (cross sectional) varies.

First case: When " $\mathrm{i}$ " (cross section) is constant:

$$
\begin{aligned}
& \mathrm{t}=1 \mathrm{Y}_{\mathrm{i} 1}=\alpha+\beta \mathrm{Y}_{\mathrm{i} 1}+\mathrm{U}_{\mathrm{i} 1} \\
& \mathrm{t}=2 \mathrm{Y}_{\mathrm{i} 2}=\alpha+\beta \mathrm{Y}_{\mathrm{i} 2}+\mathrm{U}_{\mathrm{i} 2} \\
& \mathrm{t}=3 \mathrm{Y}_{\mathrm{i} 3}=\alpha+\beta \mathrm{Y}_{\mathrm{i} 3}+\mathrm{U}_{\mathrm{i} 3} \\
& \mathrm{t}=\mathrm{T} \mathrm{Y}_{\mathrm{iT}}=\alpha+\beta \mathrm{Y}_{\mathrm{iT}}+\mathrm{U}_{\mathrm{iT}}
\end{aligned}
$$

Second case: when " $\mathrm{t}$ " (time series) is constant:

$$
\begin{aligned}
& \mathrm{i}=1 \mathrm{Y}_{\mathrm{it}}=\alpha+\beta \mathrm{Y}_{1 \mathrm{t}}+\mathrm{U}_{1 \mathrm{t}} \\
& \mathrm{i}=2 \mathrm{Y}_{2 \mathrm{t}}=\alpha+\beta \mathrm{Y}_{2 \mathrm{t}}+\mathrm{U}_{2 \mathrm{t}} \\
& \mathrm{i}=3 \mathrm{Y}_{3 \mathrm{t}}=\alpha+\beta \mathrm{Y}_{3 \mathrm{t}}+\mathrm{U}_{3 \mathrm{t}} \\
& \mathrm{i}=\mathrm{N} \mathrm{Y}_{\mathrm{Nt}}=\alpha+\beta \mathrm{Y}_{\mathrm{Nt}}+\mathrm{U}_{\mathrm{Nt}}
\end{aligned}
$$

The results from the pooled data model are presented in Table 2.

The main difference between fixed effect and random effect model lies in dummy variables role. If dummies act as part of error term, then we can say it is in random effect mode. Meanwhile, if dummies are part of the intercept, then it falls into fixed effect model. In fixed effects model, the effects are time invariant and they are considered part of the intercept, which allowed to be correlated to other regressors. However, in the case of random effect model (assuming that intercept is part of errors term), the effects should not be correlated to any regressors (which is one of the core OLS assumptions). To do so, we will use Hausman (1978) specification test to identify which effect (fixed effect or random effect) is more suitable for our research model. In Hausman specification test, the null hypothesis states that the individual effect is uncorrelated with other regressors in the model. If $\mathrm{H}_{0}$ rejected, we will proceed with the fixed effect model. However, if the null hypothesis is accepted, a fixed effect model is said to produce biased results and so the random effect model is preferred. Later, the fixed effects model will be tested by incremental F-test, while random effects will are examined by Lagrange Multiplier (LM) test.

The fixed effect model can be written in three different structures:

$$
\begin{gathered}
Y_{i t}=\alpha+U_{i}+\beta Y_{i t}+U_{i t} \\
Y_{i t}=\alpha+\Delta_{t}+\beta Y_{i t}+U_{i t} \\
Y_{i t}=\alpha+Y_{i}+\Delta_{t}+\beta Y_{i t}+U_{i t}
\end{gathered}
$$

We adopt structure 3 in this study because it is more enlightening to analyze the fixed effect model. We will identify the impact of individual and time series on the intercept. Here, if the effect is purely going to intercept, then we are observing it through $\Upsilon_{i}$. However, if it is moving towards the time series, then it will be on $\Delta_{t . . .}$ If we will observe both movements, then we will combine $\Upsilon_{i}$ with $\Delta_{t}$.

The mathematical expression is shown below:

$$
\text { Yit }=\alpha+\gamma_{2} W_{2 t}+\gamma_{3} W_{3 t}+\ldots \ldots \ldots \ldots . \gamma_{N} W_{N t}+\Delta_{2} Z_{i 2}+\Delta_{3} Z_{i 3} \ldots \ldots \ldots \ldots \ldots . . \Delta_{T} Z_{i T}+\beta X_{i t}+U_{i t}
$$

Where: $\mathrm{W}_{\mathrm{it}}$ and $\mathrm{Z}_{\mathrm{it}}$ are dummies

A dummy variable is used in panel setup. One dummy variable will observe through time series issue and the second dummy variable will observe through the cross sectional issue.

$\mathrm{W}_{\mathrm{it}}=\{1$ (if $\left.\mathrm{I}=1,2,3, \ldots \ldots \ldots . \mathrm{N})\right\}$ then equal to " 0 " otherwise

$Z_{\text {it }}=\{1$ (period only) $t=1 \ldots \ldots . T\}$ " 0 " otherwise

In the case of fixed effect modeling, we use F- statistics.

$$
\left.\mathrm{F}=\mathrm{RSS}_{\mathrm{OLS}} \mathrm{RSS}_{\mathrm{MET}} / \mathrm{RSS}_{\mathrm{MET}} \ldots \ldots . . . . \text { (Divided by unrestricted } \mathrm{RSS}_{\mathrm{MET}}\right)
$$

\section{NT-N-T/N+T-2 $=(\mathrm{NT}-\mathrm{N}-\mathrm{T})$ Degrees of freedom}

In case of fixed effect model, the ordinary least squares (OLS) estimation method is deployed to analyze the data. Both least squares dummy variable model (LSDV) and within effect model are used. The least squares dummy 
variable model (LSDV) uses dummy variable, but within effect model does not use dummy variable to estimate fixed effect. In case of fixed effect, we observe the individual and the time series effects on the intercept.

With regard to random effect model, the first variance components will be calculated using the method described by Fuller and Bates as well as Wallace and Hussain. Random effect model will be more efficient if $\alpha$ i is uncorrelated with the explanatory variables (regressors). Generalized Least square (GLS) is used to estimate the random effect model (when the variance structure is known) and the Feasible Generalized least squares (FGLS) method is used to estimate random effect model in the event variance structure is unknown.

$$
\mathrm{Y}_{\mathrm{it}}=\alpha+\beta \mathrm{Y}_{\mathrm{it}}+\mathrm{U}_{\mathrm{it}} \ldots \ldots \ldots \ldots \ldots \ldots . . .\left(\text { where } \mathrm{U}_{\mathrm{it}}=\mathrm{U}_{\mathrm{i}}+\mathrm{V}_{\mathrm{t}}+\mathrm{W}_{\mathrm{it}}\right)
$$

In random effect model, the effects will be directly observed from the error terms.

where:

$\mathrm{U}_{\mathrm{i}}=$ Error due to cross section component

$\mathrm{V}_{\mathrm{t}}=$ Error due to time series

$\mathrm{W}_{\mathrm{it}}=$ Error due to both " $\mathrm{i}$ " and " $\mathrm{t}$ " components

Here, the standard assumption is that

$\mathrm{U}_{\mathrm{it}} \sim \mathrm{N}\left(0, \sigma^{2} \mathrm{U}\right) \ldots . .$. .. (It will normally distribute with " 0 " and constant variance)

$\mathrm{V}_{\mathrm{t}} \sim \mathrm{N}\left(0, \sigma^{2} \mathrm{~V}\right) \ldots . .$. . (It will normally distribute with " 0 " and constant variance)

$\mathrm{W}_{\mathrm{it}} \sim \mathrm{N}\left(0, \sigma^{2} \mathrm{~W}\right)$.........(It will normally distribute with "0" and constant variance)

Before the study could proceed further, all the above three assumptions must be satisfied.

$\operatorname{Var}\left(\mu_{\mathrm{it}}\right)=\Upsilon^{2} \mathrm{U}+\Upsilon^{2} \mathrm{~V}+\Upsilon^{2} \mathrm{~W} \ldots \ldots \ldots \ldots . .\left(\right.$ where $\mu_{\mathrm{it}}=$ Total Variance $)$

For OLS (pooled) estimation, $\operatorname{Var}\left(\mu_{\mathrm{it}}\right)=\Upsilon^{2} \mathrm{~W}$.

Here, we have two different cases for consideration.

Case $1 \rightarrow$ If $\sigma^{2} U=Y^{2} V$, then we will use OLS estimation.

Case $2 \longrightarrow$ If $\sigma^{2} U \neq Y^{2} \mathrm{~V}$, the we will proceed with GLS estimation technique.

In case 2, we will use two-step process where we first apply OLS at random equation model and later calculate the RSS to estimate the sample variance. Then, we apply the GLS estimation techniques.

\subsection{Model Representation}

$$
F D I_{i t}=\alpha+\beta 0+\beta 1 T D_{i t}+\beta 2 I N F_{i t}+\beta 3 B L R_{i t}+\beta 4 G D P_{i t}+\mu_{i t}
$$

Where:

$\beta 0$ is the intercept;

' $t$ ' is a time specific effect $(t=1, \ldots . . T)$;

' $i$ ' is cross section specific effect $(i=1 \ldots \ldots N)$;

$\mu_{i t}$ is the error term effect;

$F D I=$ Foreign Direct Investment;

$T D=$ Technological capabilities);

$I N F=$ Inflation;

$B L R=$ Basic Lending rate;

$G D P=G D P$ growth Rate \%,

In the case of fixed effects regression model, we use the dummy variables in the dataset with the understanding that each country has different effect from one another. Also, we assume that time effect is also different from each other together with the cross-sectional elements. In fixed effect models, we assume that each country has different $\mathrm{Y}$ intercept. We can put only two dummy variables due to the total of three (3) cross sections (Pakistan, India, and Bangladesh). The study also includes seventeen (17) dummy variables into the model due to the presence of total eighteen (18) time series (18 yearly data on each country). 


\subsection{Empirical Findings}

We use balanced panel data to estimate technology capability as a key determinant of FDI in Indian sub-continent over the period of 1994-2011 using 54 panel data observations. Inflation (INF), Basic Landing Rate (BLR) and GDP Growth Rate \% are also included in this study in order to identify key variables that led countries in Indian sub-continent to high FDI. Before proceeding to static panel data model analysis, the correlation matrix will be estimated to see the correlation between the variables.

Table 1. Correlation matrix

\begin{tabular}{llllll}
\hline & FDI & TD & INF & BLR & GDP \\
\hline FDI & 1 & & & & \\
TD & 0.82392 & 1 & & & \\
INF & 0.1598 & 0.08457 & 1 & & \\
BLR & -0.3585 & -0.4269 & 0.14805 & 1 & \\
GDP & 0.36188 & 0.47634 & -0.1013 & -0.4146 & 1 \\
\hline
\end{tabular}

$\mathrm{TD}=$ Technology development. INF $=\overline{\text { Inflation. } \mathrm{BLR}=\text { Basic Landing rate. GDP }=\text { GDP growth Rate } \% . ~}$

Table1 finding indicates that country technology development was highly correlated with dependent variable FDI showing 0.823, while Inflation and Basic Lending Rate and GDP Growth Rate showed low correlation. This gives us the clear indication that technology capabilities do has effects on countries foreign direct investment which leads us to proceed further.

Table 2. Pooled data model

\begin{tabular}{llll}
\hline & Estimate & $\mathrm{t}$ Value & $\operatorname{Pr}>|\mathrm{t}|$ \\
\hline Intercept & 4.717 & 0.11 & 0.9099 \\
TD & 3.63101 & 10.5 & $<.0001$ \\
INF & 1.47 & 1.16 & 0.2525 \\
BLR & 3.861 & 0.15 & 0.8782 \\
GDP & -2786 & -0.94 & 0.3543 \\
R-Square & 0.8725 & & \\
\hline
\end{tabular}

$\mathrm{TD}=$ Technology development. INF $=$ Inflation. $\mathrm{BLR}=$ Basic Landing rate. GDP $=$ GDP growth Rate $\%$.

Pooled (OLS) estimates are presented in Table 2 showing that a country's technology development was highly significant at $1 \%(0.0001)$. P-value test hypothesis is that each coefficient is different from zero. In this case, p-value 0.0001 indicates that technological development had effects on dependent variable FDI and the remaining variables including GDP growth, and basic landing rate were not statistically significant. Furthermore, in Table 2 the results show that all remaining 3 variables were not significant. Also, t-value result also reveals statistical significant value of 10.5 , which indicated that country domestic technological capabilities had positive and significant influence on dependent variable FDI. Hypothesis of t-values test is that each coefficient is different from zero. To reject a hypothesis, the t-value has to be higher than 1.96 (for a $95 \%$ of confidence). The model is considered a good fitted model if the R-Square is highly significant. Pooled Estimate result shows R-Square 0.8725 , which was closer to 1.0.

Table 3. Fixed two-way

\begin{tabular}{llll}
\hline & Estimate & tValue & $\operatorname{Pr}>|t|$ \\
\hline Intercept & -2114 & -0.38 & 0.7053 \\
TD & 4.197 & 5.02 & $<.0001$ \\
INF & 1.229 & 0.59 & 0.5594 \\
BLR & -2997 & -0.01 & 0.9927 \\
GDP & -28250 & -0.6 & 0.5516 \\
R-Square & 0.9321 & & \\
F Test & 0.232 & & \\
\hline
\end{tabular}

$\mathrm{TD}=$ Technology development. INF $=$ Inflation. $\mathrm{BLR}=$ Basic Landing rate. GDP $=$ GDP growth Rate $\%$. 
In Static Panel data setup, the data using Fixed Effects and Random Effect Model are analyzed. In Table 3, a result for Two-Way Fixed Effect Model which shows significant p-value at $1 \%$, followed by significant $\mathrm{t}$-statistics is presented. The finding indicates that the variable had significant influence on the dependent variable. R-Squared result also showed large value.

Table 4. F-Test for no fixed effects

\begin{tabular}{llll}
\hline Num DF & Den DF & F Value & Pr $>$ F \\
\hline 19 & 29 & 1.34 & 0.232 \\
\hline
\end{tabular}

However, looking at the F-test result in Table 4, which is not significant, it leads us to analyze the same data using the Random Effect models. The Null Hypothesis of F-test is that there were no fixed effects. Hausman Test is also used to indicate either Random Effect or Fixed Effect Model would be more suitable for analyzing our research data. The remaining variables including GDP growth, and basic landing rate were not statistically significant.

Table 5. Random two (Fuller and Battese)

\begin{tabular}{llll}
\hline & Estimate & tValue & $\operatorname{Pr}>|\mathrm{t}|$ \\
\hline Intercept & 10413 & 0.26 & 0.7972 \\
TD & 3.623 & 10.76 & $<.0001$ \\
INF & 1.43 & 1.1 & 0.2748 \\
BLR & 10.24 & 0.04 & 0.9666 \\
GDP & -3101 & -1.04 & 0.3045 \\
R-Square & 0.8799 & & \\
F Test & & & \\
Hausman Test & 0.9669 & & \\
\hline
\end{tabular}

$\mathrm{TD}=$ Technology development. INF = Inflation. BLR= Basic Landing rate. GDP = GDP growth Rate $\%$.

Two-Way Random Effect Model is utilized in Table 5 using Fuller and Battese Variance Components which also shows positive estimate value following significant p-value of 0.0001 and the t-value test indicates 10.76 . The result was consistent with Pooled Data Model and Two-Way Fixed Effect Model. So far, our finding clearly indicates that technological developments have positive effects on Countries FDI inflow in Indian sub-continent and can be considered one of the key determinants of FDI inflow. R-square represented large value at 0.876 , which showed reasonable fit in this model.

Table 6. Hausman test for random effects

\begin{tabular}{lll}
\hline DF & m Value & $\operatorname{Pr}>\mathrm{m}$ \\
\hline 5 & 0.94 & 0.9669 \\
\hline
\end{tabular}

Till now we have results from both Fixed Effect and Random Effects Model, within the panel data setup. To identify which method will best fit into our model, we run the Hausman test. In Hausman (1978) specification test the Null Hypothesis is that, the individual effect is uncorrelated with other regressors in the model. If $\mathrm{H}_{0}$ is rejected, we will proceed with the Fixed Effect Model. However, if the Null Hypothesis is accepted, a Fixed Effect Model will produce biased results. Therefore, the Random Effect Model is preferred. Based on Table 6, Hausman Test result showed 0.96, which clearly leads us to use Random Effect Model in this study, as a Fixed Effect Model will generate base results due to Hausman test which was not significant in 0.05. 
Table 7. Random one (Fuller and Battese )

\begin{tabular}{llll}
\hline & Estimate & tValue & $\operatorname{Pr}>|\mathrm{t}|$ \\
\hline Intercept & 4.487 & 0 & 0.999 \\
TD & 3.656 & 10.33 & $<.0001$ \\
INF & 1.388 & 1.07 & 0.287 \\
BLR & 6.864 & 0.26 & 0.794 \\
GDP & -2432 & -0.78 & 0.438 \\
R-Square & 0.8509 & & \\
F Test & & & \\
Hausman Test & 0.2799 &
\end{tabular}

To investigate further, we used One-Way Random Model in Table 7 and its result clearly shows the positive estimation followed by highly significant p-value at $1 \%(0.0001)$ and Positive t-value test.

One-Way Random Model includes only one set of dummy variables. Data are further analyzed with Two-Way Random Effect Model using Wallace and Hussain Variance Components (Ran Two) in Table 8 which also shows the same optimistic result.

Table 8. Random two Wallace and Hussain

\begin{tabular}{llll}
\hline & Estimate & tValue & $\operatorname{Pr}>|\mathrm{t}|$ \\
\hline Intercept & 1.3179 & 0.33 & 0.741 \\
TD & 3.619 & 10.88 & $<.0001$ \\
INF & 1.4766 & 1.07 & 0.29 \\
BLR & -2924 & -0.01 & 0.99 \\
GDP & -3257 & -1.09 & 0.282 \\
R-Square & 0.8835 & & \\
F Test & & & \\
Hausman Test & 0.971 & &
\end{tabular}

\section{Discussion}

In recent years, India is more focused on economic strengths by developing new economic policy, mass IT industry, possession of high IT skill labors, and increasing technological capacity with high yields from a vibrant capital market. This in turn directly increases the country innovative capacity that leads to comparative advantages in terms of inward Foreign Direct Investment (FDI). On the contrary, Pakistan and Bangladesh failed to develop their technological capacity that directly increases countries innovative capabilities and to provide base structure for other industries. Today, Pakistan and Bangladesh experience slow economic growth with continued political instability, and both countries are looking for policies that will stimulate growth and create new jobs.

Technology is the fastest growing industry, especially the Information technology (IT) that directly creates millions of jobs in India and supports the other industry so as to increase productivity and improve the production process. Amitendu Palit (2007) argues that countries in the region, which can develop long-term sources of comparative advantages in the form of superior technological capacities and high-level technological workforce and supporting infrastructures, have consistently attracted greater volumes of export oriented FDI. Today, Indian information technology industry only creates 2.7 million professional jobs with an increase of $10 \%$ every year. India provides high skill IT related workforce to the world market, especially Singapore and the United States. This is the reason why today Indian software industry is considered one of the highly potential industries in Indian-subcontinent. 
As we live in the information age today, technology is considered the basic tool for countries economic development. Without the help of technological infrastructure, having capital alone cannot be the determinant for countries economic development and foreign direct investment. As far as India is concerned, it is technical development along with capital, which can boost the rate of its economic growth by attracting large numbers of inward FDI. Our finding clearly reveals that there is a statistically significant relationship between FDI inflow and countries domestic technological capabilities, which can be considered one of the key determinants of FDI in Indian sub-continent. Furthermore, our finding indicates that inflation, GDP growth, basic lending rate do not affect regional FDI. But those variables may have different effects on inward FDI in different individual country. India has been showing high technological development during the last few decades and is able to attract high FDI, followed by Pakistan and Bangladesh. Technology is the single industry which can support the overall industries, and make them more efficient in their operations to increase productivity.

Traditionally, the low labor cost is considered a pull economic factor to attract more FDI. Our finding suggests that in today's complex production processes, countries are required to increase their technological capabilities focusing on building domestic technology, which can lead to more innovative capacities and FDI inflow. The study concludes that the determinant of FDI is shifting from low labor cost and high population to more efficiency seeking in Indian sub- continents. The labor cost is much higher in India as compared to Bangladesh and Pakistan, but India is still able to attract more foreign investment.

Our finding suggests that in today's competitive global business markets, the differences in technology are a key factor that influences the foreign direct investment (FDI) pattern in Indian sub-continent. India has the economic advantage over Pakistan and Bangladesh simply because its software industry has vast growth potential, and is blessed with a large pool of skilled IT professionals who provide strong support to other industries in the country as well as attracting a number of multinational companies (MNCs) for business investment. The MNCs are always searching for innovative capability, and countries domestic technological capabilities that can directly reflect on the role of innovation.

\section{Conclusion}

Indian sub-continent has a huge potential for attracting large FDI inflow, but Pakistan and Bangladesh still need to recognize the realities of the global investment market. Foreign investors in Indian sub-continent not only look for monetary concessions and special incentives or low labor cost, but they also focus on countries domestic capability, political stability, security of investment, and technological capabilities to improve the business process. This gives us a clear direction that FDI flows to Indian sub-continent is efficiency seeking rather than market seeking or resource seeking.

To achieve these objectives, multinational companies (MNCs) will always look for skillful human resource, more advance technology with low cost, which can reduce production cost and improve efficiency in the form of innovation or production process. To understand type of FDI, it's important to know that different type of FDI will have different motivation factors. Domestic IT skillful workforce and domestic technology capabilities are the few main reasons that India attracts large number of efficiency seeking FDI, while Pakistan and Bangladesh need to understand the regional FDI trend and provide more location advantage for efficiency seeking FDI.

In spite of this reason, MNCs, however, prefer to search for foreign locations where advance technology is easily available with cheaper price, for example India and China rather than investing in countries with low labor cost such as Bangladesh and Pakistan. Furthermore, the multinational companies (MNCs) will prefer to invest in countries with high domestic technological capabilities such as USA, India, and China in order to minimize the production cost. As for Pakistan and Bangladesh, one of the factors that contribute to the low FDI inflow to the countries is because they have low domestic technological capabilities unlike their counterpart, India. A country with high domestic technological capabilities will be able to stimulate a long-term economic growth and attract more efficiency seeking FDI.

Technological capabilities are not only the fundamental component for attracting FDI in Indian subcontinent, but they also play the main role in achieving substantive goals such as quality of life or higher income per capital. Based on our study, we do point out that those variables may have a different role in different countries, and certainly, we do not expect that the same variable will have the same importance across countries. Here, our recommendation for Pakistan and Bangladesh policy maker is to provide strong location advantage for efficiency seeking FDI with technological infrastructure and support new business. Moreover, they need to understand the changes in global investment market and regional trend in order to attract inward FDI. 


\section{References}

Arnold, E., Bell, M., Bessant, J., \& Brimble, P. (2000). Enhancing Policy and Institutional Support for Industrial Technology Development in Thailand. Technopolis, Brooker Group PLC, December 2000.

Balasubramanyan, V. (1996). FDI and Growth in EP and IS countries. The Economic Journal.

Biswas, R. (2002). Determinants of foreign direct investment. Review of Development Economics.

Borensztein, E., Gregorio, J., \& Lee, J. (1995). How does foreign direct investment affect economic growth? Journal of International Economics.

Bosworth, B., P., \& Collins, S. M. (1999). Capital flows to developing economies: Implications for saving and investment. Brookings Papers on Economic Activity, 1, 143-169.

Chakraborty, C., \& Basu, P. (2002). Foreign Direct Investment and Growth in India: A Cointegration Approach. Applied Economics.

Chakraborty, C., \& Nunnenkamp, P. (2008). Economic Reforms, FDI, and Economic Growth in India: A Sector Level Analysis. World Development.

Demello, L. R. (1999). Foreign Domestic Investment-Led Growth: Evidence from Time Series and Panel data. Oxford Economic Papers.

Durham, J. B. (2004). Absorptive Capacity and the effects of Foreign Direct Investment and equity foreign Portfolio investment on Eco Growth. European Economic Review, 48, 285-306.

EMCO. (2005). Presentation on "Vocational Education and Training in Modern Manufacturing Technology". Higher Education Commission (HEC). Pakistan Institute of Development Economics

Encarnation D. J., \& Wells, L. T. (1986). Evaluating foreign investment. In T. H. Moran et al. (Eds.), Investing in development: new roles for foreign capital? Washington, DC: Overseas Development Council.

Engineering Development Board (EDB). (n.d.). Ministry of Industries, Production \& Special.

Ericsson, J., \& Irandoust, M. (2000). On the causality between foreign direct investment and output: A comparative study. International Trade Journal.

Initiatives, Government of Pakistan. (2006). Draft Auto Industry Development Programme (AIDP).

Lall, S. (2001). Competitiveness, Technology and Skills, Cheltenham: Edward Elgar. In S. Lall, \& J. Weiss (Eds.), Industrial Competitiveness: The Challenge for Pakistan.

Nazima, E. (2012). Bounds Testing Approach to Find the Impact of Capital Inflow on Real Output Growth of Pakistan. International Journal of Economics and Finance, 4(4). http://dx.doi.org/10.5539/ijef.v4n4p106

Pakistan Council for Science \& Technology (PCST). (2005). Science and Technology Policy Indicators of Pakistan. Islamabad. Approach Paper for Vision 2030.

\section{Notes}

Note 1. Technological Activity Index (TAI) is measured by countries technological development Broadcast by UNCTAD. Here our technological Development data are the weighted average of three different technological advancement parameters, which include Manpower working in Research \& Development, Total patents local and international, and the scientific journal issue by each country's. Data used in this research are the weighted average of all three parameters. SAS is used to analyze the data.

Note 2. By technology, we simply mean the body of knowledge that can be used to produce goods and services and by technological capabilities, we mean the increased application of new scientific knowledge that can lead to more effective and innovations from economic resources.

\section{Copyrights}

Copyright for this article is retained by the author(s), with first publication rights granted to the journal.

This is an open-access article distributed under the terms and conditions of the Creative Commons Attribution license (http://creativecommons.org/licenses/by/4.0/). 